STUDI DESKRIPSI STATUS FUNGSIONAL PASIEN KANKER PAYUDARA DENGAN KEMOTERAPI
NURSCOPE

Jurnal Keperawatan dan Pemikiran IImiah

Hartanti, R.D., \& Wijiastuti, U. (2018). Studi Deskripsi Status Fungsional Pasien Kanker Payudara dengan

Kemoterapi.

Nurscope. Jurnal Keperawatan Pemikiran Ilmiah.

4(1).61-65

\author{
Rita Dwi Hartanti ${ }^{1}$, Utari Wijiastuti ${ }^{2}$ \\ ${ }^{1,2}$ Program Studi Sarjana Keperawatan dan Profesi Ners, Stikes Muhammadiyah Pekajangan Pekalongan
}

\begin{abstract}
ABSTRAK
Kemoterapi dapat mengubah status fungsional pasien kanker payudara. Tujuan penelitian adalah menggambarkan status fungsional pasien kanker payudara yang menjalani kemoterapi, dengan desain analisis deskriptif. Sampel penelitian adalah seluruh pasien kanker payudara dengan kemoterapi di RSUD Kraton Kabupaten Pekalongan. Jumlah responden sebanyak 46 responden, dengan metode total sampling. Hasil penelitian $67,4 \%$ memiliki penilaian status fungsional berada pada kategori A artinya mandiri pada 6 fungsi kegiatan meliputi fungsi mandi, berpakaian, toileting, berpindah, kontinen dan makan. 10,9\% responden mempunyai status fungsional kategori F. 4,3 \% responden memiliki status fungsional kategori B, C, D, E, dan G. Peningkatan asuhan keperawatan secara komprehensif diperlukan untuk meningkatkan status fungsional pasien kanker payudara yang menjalani kemoterapi.
\end{abstract}

Kata kunci: Status fungsional, kanker payudara, kemoterapi

\title{
DESCRIPTIVE STUDY OF FUNCTIONAL STATUS BREAST CANCER PATIENTS WITH CHEMOTHERAPY
}

ABSTRACT

Chemotherapy can experience changes in functional status breast cancer patients. The purpose of this study was to describe the functional status of breast cancer patients with chemotherapy, with design uses descriptive analysis. The sample is all breast cancer patients with chemotherapy at RSUD Kraton Kabupaten Pekalongan. The respondents is 46 , with sampling method used total sampling. The results of this study is $67.4 \%$ had an assessment of functional status in category A which meant that they were independent in 6 function including the functions of bathing, dressing, toileting, moving, continental and eating. $10.9 \%$ of respondents have functional status category F. $4.3 \%$ of respondents have functional status categories $B, C, D, E$, and $G$. Comprehensive nursing care is needed to improve the functional status of breast cancer patients with chemotherapy.

Keywords: functional status, breast cancer, chemotherapy

Corresponding Author

Rita Dwi Hartanti ${ }^{1}$, Program Studi Sarjana Keperawatan dan Profesi Ners, Stikes Muhammadiyah Pekajangan Pekalongan, E-mail: rita.270985@gmail.com

\section{PENDAHULUAN}

Kanker payudara merupakan jenis kanker yang sering ditakuti oleh wanita. World Health Organization (WHO) menyatakan kasus kanker payudara di seluruh dunia 50\% ditemukan di negara berkembang. Setiap tahun pasien kanker payudara di RSUD Kraton mengalami peningkatan. Tahun 2014 ada 36 orang, tahun 2015 terdapat 42 orang, tahun 2016 sebanyak 46 orang dan 64 orang di tahun 2017. 
Kemoterapi merupakan salah satu terapi pada kanker payudara untuk menghancurkan sel kanker yang bekerja secara sistemik. Pemberian kemoterapi pada pasien dengan kanker dapat menimbulkan dampak fisik maupun dampak psikologis. Dampak fisik yang terjadi diantaranya adalah supresi pada sumsum tulang, perubahan pada sistem pencernaan (mual, muntah, konstipasi atau diare), perubahan pada sistem saraf, alopesia dan kelemahan.sedangkan perubahan secara psikologis dapat mengakibatkan perubahan emosi dan gangguan mood. Frekuensi pemberian kemoterapi yang sering juga akan mempengaruhi status fungsional pasien kanker (Rasjidi, 2010).

Melia (2013) dalam penelitiannya menyatakan minimal frekuensi tindakan kemoterapi yang diberikan kepada responden adalah dua kali dan frekuensi maksimal delapan kali, dengan nilai status fungsional rata-rata sebesar 24,03 , dengan nilai terkecil 12 dan nilai terbesar 37 . Status fungsional digunakan untuk melakukan pengukuran dan penilaian secara multidimensional tingkat kemandirian seseorang yang meliputi penilaian kesejahteraan fisik, psikologis dan sosial individu. Penilaian status fungsional pada Dimensi fisik meliputi kemampuan untuk bekerja dan berfungsinya fisik. Sedangkan penilaian pada dimensi psikologis meliputi koping, kemampuan, penerimaan diri, status kesehatan yang dirasakan dan penyesuaian terhadap penyakit (Sayed \& Badr, 2014).

\section{METODE PENELITIAN}

Metode penelitian yang digunakan metode deskripstif analisis yang bertujuan untuk mengetahui status fungsional pasien kanker payudara dengan kemoterapi. Adapun penelitian dilakukan di RSUD Kraton Kabupaten Pekalongan pada tanggal 12-31 januari 2018. Sampel penelitian adalah pasien kanker payudara yang mendapatkan kemoterapi sebanyak 46 responden dengan kriteria inklusi adalah 1) pasien kanker payudara dengan tingkat kesadaran composmentis, 2) pasien kanker payudara yang tidak mengalami komplikasi saat pengambilan data penelitian berlangsung. Teknik sampel menggunakan sampel jenuh (total sampling). Instrumen penelitian adalah kuesioner status fungsional dengan menggunakan indeks Katz yang meliputi enam fungsi kemandirian responden yaitu mandi, berpakaian, toileting, berpindah, kontinen dan makan, dengan penilaian Skor 6 yaitu jika mandiri semua fungsi dengan kategori Status Fungsional kategori A, skor 5 yaitu mandiri semua fungsi kecuali pada satu fungsi tertentu dengan kategori B, skor 4: jika mandiri di semua fungsi kecuali mandi dan satu fungsi tambahan dengan kategori C, skor 3: jika jika mandiri di semua fungsi kecuali pada mandi, berpakaian dan satu fungsi dengan kategori $D$, skor 2: jika jika mandiri di semua fungsi kecuali apda mandi, berpakaian, toileting dan satu fungsi tambahan dengan kategori E, skor 1 : jika jika mandiri di semua fungsi kecuali pada mandi, berpakaian, toileting, berpindah dan satu fungsi tambahan dengan kategori $\mathrm{F}$ dan skor 0 , tergantung di semua keenam fungsi dengan kategori G. Analisis data yang dilakukan berupa analisis univariat untuk mendeskripsikan distrbusi frekuensi dan persentase variabel penelitian.

\section{HASIL}

Hasil penelitian digambarkan melalui tabel distribusi berikut ini:

Distribusi Frekuensi Status Fungsional PasienKemoterapi dengan Kanker Payudara di RSUD Kraton Pekalongan $(n=46)$

\begin{tabular}{ccc}
\hline Status Fungsional & Frekuensi & Persentase (\%) \\
\hline A & 31 & 67,4 \\
B & 2 & 4,3 \\
C & 2 & 4,3 \\
D & 2 & 4,3 \\
E & 2 & 4,3 \\
F & 5 & 10,9 \\
\hline
\end{tabular}




\begin{tabular}{ccc}
\hline Status Fungsional & Frekuensi & Persentase (\%) \\
\hline G & 2 & 4,3 \\
\hline Total & $\mathbf{4 6}$ & $\mathbf{1 0 0}$ \\
\hline
\end{tabular}

Berdasarkan tabel tersebut dapat diketahui status fungsional pasien kanker terbanyak terdapat pada kategori A yaitu sebanyak 67,4 \%, sedangkan status fungsional dengan kategori B, kategori C, Kategori D, kategori $\mathrm{E}$ dan Kategori $\mathrm{G}$ sebanyak 4,3\%. Untuk responden dengan status fungsional kategori $\mathrm{F}$ terdapat sebanyak $10,9 \%$.

\section{PEMBAHASAN}

Kanker payudara merupakan salah satu tipe kanker yang menjadi perhatian bagi seorang wanita. Kondisi kanker payudara merupakan salah satu pemicu yang menyebabkan stress yang dapat mempengaruhi status fungsional. Perubahan status fungsional pada pasien kanker dapat terjadi akibat berbagai perubahan status kesehatan pasien kemoterapi baik secara fisik maupun secara psikologis. Berbagai dampak dan komplikasi kemoterapi menjadi pertimbangan penting terhadap perubahan status fungsional pasien kemoterapi. Perubahan yang sering terjadi pada pasien kemoterapi diantaranya kecemasan, depresi, keletihan serta perubahan kondisi secara fisik yang tidak dapat diprediksi sebelumnya seperti demam, sesak napas, mual. Muntah dan tidak nafsu makan (Schopfer, Regan, Heidenreich, \& Whooley, 2016).

Status fungsional digunakan untuk mengkaji riwayat kesehatan dan kemampuan fisik pada pasien dengan kanker. Penilaian status fungsional merupakan penilaian terhadap kemampuan melakukan aktivitas sehari-hari seseorang secara mandiri. Penilaian tersebut meliputi kemampuan melakukan aktivitas mandi, berpakaian, makan, berpindah dan toileting (Overcash, 2015). Kondisi penyakit kronik seperti kanker payudara dengan penatalaksanaan kemoterapi dapat berdampak pada perubahan status fungsional pasien (Harrison et al., 2017). Status fungsional sangat penting bagi pasien kanker karena status fungsional merupakan salah satu cara untuk mengevaluasi perkembangan dan dampak dari penatalaksanaan kemoterapi yang dilakukan pasien kanker payudara. Perubahan status fungsional pasien juga menjadi acuan bagi perawat untuk menentukan kebutuhan perawatan pasien selama asuhan keperawatan diberikan (Wefel \& Schagen, 2012).

Penilaian status fungsional dalam penelitian ini diukur dengan mengukur kemampuan pasien melakukan aktivitas sehari-hari dengan Indeks Kartz. Pengukuran kemampuan melakukan aktivitas sehari-hari dengan melihat kemandirian pasien dalam melakukannya. Penilaian tersebut meliputi kemampuan dalam aktivitas mandi, berpakaian, toileting, berpindah, kontinen dan makan. Penilaian skroing yang dilakukan dalam penelitian ini adalah Skor 6 yaitu jika mandiri semua fungsi aktivitas, skor 5 yaitu jika terdapat salah satu fungsi yang tidak dilakukan secara mandiri, skor 4: jika mandiri di semua fungsi kecuali pada fungsi aktivitas mandi dan satu fungsi tambahan, skor 3: jika mandiri di semua fungsi kecuali pada aktivitas mandi, berpakaian dan satu fungsi aktivitas yang lain, skor 2: jika mandiri di semua fungsi kecuali pada aktivitas mandi, berpakaian, toileting dan satu fungsi aktivitas tambahan lainnya, skor 6 : jika mandiri di semua fungsi kecuali pada mandi, berpakaian, toileting, berpindah dan satu fungsi ainnyatambahan Is dan skor 0 , tergantung di semua keenam fungsi aktivitas.

Data penelitian menyebutkan sebagian besar $(67,4 \%)$ responden mempunyai status fungsional A. status fungsional A menunjukkan bahwa individu berada pada kemampuan melakukan aktivitas secara mandiri pada semua fungsi, yang meliputi kemampuan melakukan fungsi mandi, berpakaian, toileting, berpindah, kontinen dan makan. Penelitian ini juga mengambarkan terdapat 10,9\% responden mempunyai status fungsional $\mathrm{F}$ yang memiliki arti responden tidak dapat melakukan kemampuan mandi, berpakaian, 
toileting, berpindah dan makan secara mandiri, tetapi responden dapat melakukan kontinensi secara mandiri atau tanpa menggunakan alat. Hasil penelitian ini juga menggambarkan sebagian kecil (4,3\%) masing-masing responden mempunyai status fungsional B, C, D, E dan G.

Responden yang mempunyai status fungsional B diartikan responden dapat melakukan aktivitas kesehariannya meliputi mandi, berpakaian, toileting, berpindah dan makan secara mandiri, namun tidak dapat melakukan kontinensi secara mandiri. Responden dengan status fungsional $\mathrm{C}$ dapat melakukan kegiatan mandi, berpakaian, makan dan kontinesi secara mandiri, namun tidak dapat melakukan toileting dan berpindah secara mandiri. Responden yang mempunyai status fungsional D dapat melakukan kegiatan berpindah, makan dan kontinensi, namun tidak dapat melakukan kegiatan mandi, toileting dan berpakaian. Responden yang mempunyai status fungsional E dapat berpakaian dan makan secara mandiri, namun tidak dapat mandi, toileting, berpindah dan kontinensi. Responden yang mempunyai status fungsional G diketahui semuanya (100\%) tidak dapat melakukan kegiatan melakukan mandi, berpakaian, toileting, berpindah, makan dan kontinensi.

Status fungsional merupakan komponen penilaian kemampuan fisik individu dalam melakukan perawatan diri secara mandiri. Berbagai dampak kemoterapi yang dijalani pasien kanker payudara dapat memberikan perubahan pada status fisik dan status fungsional pasien. Anggeria (2017) dalam penelitianya menyatakan memburuknya status fungsional wanita dengan kanker payudara disebabkan karena penatalaksanaan kemoterapi yang dijalaninya dan akibat dampak ketidaknyamanan fisik yang terjadi akibat tindakan kemoterapi seperti mual, muntah, lemas, serta akibat perubahan psikologi yang dialami seperti malu, harga diri rendah. Hal ini menjadi perhatian penting perawat untuk dapat meningkatkan asuhan keperawatannya dalam memfasilitas dan meningkatkan dukungan keluarga dalam membantu meningkatkan status fungsional pasien (Linton \& Lach, 2007).

\section{SIMPULAN DAN SARAN}

Simpulan

Sebagian besar 67,4 \% pasien kanker payudara yang menjalani kemoterapi memiliki penilaian status fungsional berada pada kategori A yang berarti pasien masih dapat melakukan kegiatan aktivitas sehari hari mandiri pada kegiatan fungsi mandi, berpakaian, toileting, berpindah, kontinen dan makan. 10,9\% responden mempunyai status fungsional F. Sedangkan status fungsional kategori B, C, D, E, dan G terdapat sebanyak $4,3 \%$.

Saran

pengembangan hasil penelitian diperlukan untuk pengembangan ilmu pengetahuan sehingga diperlukan penelitian lanjutan seperti faktor yang berpengaruh terhadap status fungsional pasien kanker payudara

\section{KEPUSTAKAAN}

Anggeria, E. (2017). Hubungan Psikologis dengan Personal Hygiene Pasien Kanker Payudara di RSUD Dr. Pirngadi Medan. Fakultas Keperawatan. Program Studi Ilmu Keperawatan Fakultas Keperawatan dan Kebidanan Universitas Prima Indonesia

Dewi, R. S. (2015). Buku Ajar Keperawatan Gerontik. Yogyakarta: Deeppublisher.

Harrison, J. M., Davis, M. A., Barton, D. L., Janz, N. K., Pressler, S. J., \& Friese, C. R. (2017). Functional status and quality of life among breast cancer survivors with heart failure: results of the Medicare Health Outcomes Survey. Supportive Care in Cancer, 25(8), 2463-2473. https://doi.org/10.1007/s00520017-3653-4 
Linton, A., \& Lach, H. (2007). Gerontological Nursing Consept and Practice. Singapore: Elsevier Inc.

Melia, E. (2013). Hubungan antara Frekuensi Kemoterapi dengan Status Fungsional Pasien Kanker yang Menjalani Kemoterapi di RSUP Sanglah Denpasar. Program Studi IImu Keperawatan Fakultas Kedokteran Universitas Udayana.

Overcash, J. (2015). Assessing the Functional Status of Older Cancer Patients in an Ambulatory Care Visit. Healthcare, 3(4), 846-859. https://doi.org/10.3390/healthcare3030846

Rasjidi, I. (2010). Perawatan Paliatif Suportif dan Bebas Nyeri pada Kanker. Jakarta: Sagung Seto

Sayed, S. A., \& Badr, S. A. (2014). Deprresive Symptoms and Anxiety: Relationship to Social Support and Functional Status among Patients with Breast Cancer Surgery. Nurshing and Health Science (IOSRJNHS) .

Schopfer, D. W., Regan, M., Heidenreich, P. A., \& Whooley, M. A. (2016). Depressive Symptoms, Cardiac Disease Severity, and Functional Status in Patients With Coronary Artery Disease (from the Heart and Soul Study). American Journal of Cardiology, 118(9), 1287-1292. https://doi.org/10.1016/j.amjcard.2016.07.062

Vearncombe, K. J., Rolfe, M., Wright, M., Pachana, N. A., Andrew, B., \& Beadle, G. (2009). Predictors of cognitive decline after chemotherapy in breast cancer patients. Journal of the International Neuropsychological Society, 15(6), 951-962. https://doi.org/10.1017/S1355617709990567

Wefel, J. S., \& Schagen, S. B. (2012). Chemotherapy-related cognitive dysfunction. Current Neurology and Neuroscience Reports, 12(3), 267-275. https://doi.org/10.1007/s11910-012-0264-9

WHO. (2016). Breast Cancer: Prevention and Control. World Health Organization 